\title{
What is known about the role of rural-urban residency in relation to self-management in people affected by cancer who have completed primary treatment? A scoping review
}

\author{
David Nelson $^{1}$ (D) $\cdot$ Ian McGonagle ${ }^{1}(\mathbb{D}) \cdot$ Christine Jackson $^{1} \cdot$ Ros Kane $^{1}(\mathbb{D}$
}

Received: 2 April 2020 / Accepted: 22 July 2020 / Published online: 3 August 2020

(C) The Author(s) 2020

\begin{abstract}
Purpose Despite wide acknowledgement of differences in levels of support and health outcomes between urban and rural areas, there is a lack of research that explicitly examines these differences in relation to self-management in people affected by cancer following treatment. This scoping review aimed to map the existing literature that examines self-management in people affected by cancer who were post-treatment from rural and urban areas.

Methods Arksey and O'Malley's framework for conducting a scoping review was utilised. Keyword searches were performed in the following: Academic Search Complete, CINAHL, MEDLINE, PsycINFO, Scopus and Web of Science. Supplementary searching activities were also conducted.

Results A total of 438 articles were initially retrieved and 249 duplicates removed leaving 192 articles that were screened by title, abstract and full text. Nine met the eligibility criteria and were included in the review. They were published from 2011 to 2018 and conducted in the USA $(n=6)$, Australia $(n=2)$ and Canada $(n=1)$. None of the studies offered insight into self-managing cancer within a rural-urban context in the UK. Studies used qualitative $(n=4)$, mixed methods $(n=4)$ and quantitative designs $(n=1)$.

Conclusion If rural and urban populations define their health in different ways as some of the extant literature suggests, then efforts to support self-management in both populations will need to be better informed by robust evidence given the increasing focus on patient-centred care. It is important to consider if residency can be a predictor of as well as a barrier or facilitator to selfmanagement.
\end{abstract}

Keywords Cancer $\cdot$ Survivorship $\cdot$ Self-management $\cdot$ Urban $\cdot$ Rural

David Nelson

dnelson@lincoln.ac.uk

$\triangle$ Ros Kane

rkane@lincoln.ac.uk

Ian McGonagle

imcgonagle@lincoln.ac.uk

Christine Jackson

cjackson@lincoln.ac.uk

School of Health and Social Care, University of Lincoln, Brayford Pool, Lincoln LN6 7TS, UK

\section{Introduction}

\section{Purpose}

The growing number of people living with and beyond cancer [1], in part due to advances in early detection, diagnosis and treatment, presents significant challenges for long-term care and the management of complications and side effects of treatment. Although research indicates that the majority of people affected by cancer are interested in managing their own health and healthcare $[2,3]$, reticence to engage in lifestyle and behavioural change, or uncertainty about how to do so, have also been reported [4].

Self-management is argued to be significant at all stages of the cancer journey, particularly in the post-treatment phase, as a result of reduced involvement with, and access to healthcare professionals [5], which leads to isolation and poor access to 
post-treatment support and resources. A need for further research to enhance understanding of experiences after treatment, and to support self-management, has been acknowledged [6].

Whilst there is no 'gold standard' definition of selfmanagement [7], it has been described as 'approaches used by the individual affected by cancer (or life limiting illness) and its effects to optimise living (with the illness and its effects)' [8]. In the UK, the National Cancer Survivorship Initiative (NCSI) expanded this further and defined cancer self-management as awareness and active participation by the person affected by cancer in their recovery, recuperation and rehabilitation, to minimise the consequences of treatment, and promote survival, health and well-being [9].

Despite it being difficult to define and categorise, the concept of self-management has become well established within the cancer survivorship literature over the last decade [5, 10-22]. This has been bolstered by the shift in perception from cancer predominantly being an acute illness, to one that requires long-term management long after active treatment has ended.

Environmental factors (e.g. social and community support) have been recognised as key influencers of successful selfmanagement [15]. However, there is no explicit reference in the literature to the role or influence of rural-urban residency.

It has been documented that social and community support [22] and access to health services can differ greatly depending on where an individual lives [14], but there is still no robust evidence that explicitly examines the role of rural-urban residency in relation to self-management among people affected by cancer who are post-treatment.

Both positives and negatives to rural and urban living have been identified [22, 23]. Research within the general population has highlighted the benefits of rural living and 'green spaces' in terms of improving physical and mental health [24, 25], and there are a range of characteristics belonging to rural communities that have the potential to benefit people affected by cancer [22]. For example, rural communities frequently value close relationships with family and friends, community members and religious institutions [26], which can all be significant sources of social support [22], vital to coping with or minimising emotional distress, when experiencing a traumatic life event such as a cancer diagnosis. Rural and urban areas can differ in the availability of social support delivered in the community [22]. Indeed, qualitative work identified the benefit of increased community support experienced by women affected by breast cancer who were living in rural compared with urban areas [23]. It has been argued that future interventions need to be designed to capitalise on the high levels of community trust in rural settings [27].

Rural residents tend to have higher cancer mortality than urban residents [28, 29], and people affected by cancer in rural areas are reported to face a range of additional challenges compared with their urban counterparts [30], including longer travel distances for treatment, limited access to medical care, support services and health and social care facilities [31-33]. Other factors include unmet psychosocial needs [30, 34] as well as increased risk for poorer health outcomes [35], poorer long-term survival [36] and a lack of relevant information [30]. Furthermore, attitudinal and structural barriers to helpseeking often differ between rural and urban populations [27, 30] which could consequently influence engagement with self-management.

This review therefore aims to investigate the phenomenon of self-management in people affected by cancer who were post-treatment, and to understand the role of rural-urban residency in relation to this.

The objectives were:

- To map the existing peer-reviewed academic literature examining self-management in people affected by cancer who were post-treatment from rural and urban areas.

- To determine the extent and type of evidence available.

- To identify any gaps in the evidence for further research.

\section{Methods}

The methods for this review were based on Arksey and O'Malley's [37] five step framework for scoping reviews: (1) identifying the review question; (2) identifying the relevant studies; (3) selecting the studies; (4) charting the data; and (5) collating, summarising and reporting the results. Each individual step is reported below. The adoption of this methodological framework ensured that the review process was methodical, rigorous and transparent [38].

\section{Identifying the review question}

The question 'What is known about the role of rural-urban residency in relation to self-management in people affected by cancer who have completed primary treatment?' was developed to guide the search strategy.

\section{Identifying the relevant studies}

Parameters for searching were decided at the outset. There were no limits placed on publication dates; however, only studies in English could be included due to lack of access to funds for translation. Inclusion and exclusion criteria (see Table 1) were devised at the outset and refined again following initial searching.

The final string that was used to search was as follows: (self-manage or 'self-manage' or self-management or 'selfmanagement' AND cancer or neoplasms or oncology or 
Table 1 Inclusion and exclusion criteria

\begin{tabular}{|c|c|c|}
\hline Criterion & Inclusion & Exclusion \\
\hline Time period & Any & - \\
\hline Language & English only & Studies published in languages other than English. \\
\hline Literature & Peer-reviewed academic literature & Non-peer-reviewed academic literature \\
\hline Population & $\begin{array}{l}\text { Adults who were } 18 \text { and over who had completed primary } \\
\text { treatment for cancer. }\end{array}$ & $\begin{array}{l}\text { Under 18; people currently undergoing active cancer treatment, people } \\
\text { in receipt of palliative/end of life care. Studies exclusively on family } \\
\text { members/carers/health and social care professionals }\end{array}$ \\
\hline Study focus & $\begin{array}{l}\text { Report information on the experiences of self-management in } \\
\text { survivorship in relation to rural-urban geography. }\end{array}$ & $\begin{array}{l}\text { There is no data directly in relation to self-management and the in- } \\
\text { fluence of rural-urban geography. }\end{array}$ \\
\hline Study design & $\begin{array}{l}\text { Quantitative, qualitative and mixed methods designs as well } \\
\text { as relevant literature reviews. }\end{array}$ & - \\
\hline $\begin{array}{l}\text { Geographical } \\
\text { location of } \\
\text { study }\end{array}$ & Any & - \\
\hline
\end{tabular}

tumour or tumor or malignancy AND surviv* or 'living with cancer' or 'living with and beyond cancer' or 'affected by cancer' AND rural or remote or isolated or regional or 'small town' or community or urban or cit*).

The databases searched were as follows: Academic Search Complete, CINAHL, MEDLINE, PsycINFO, Scopus and Web of Science. This ensured that a wide range of databases relating to nursing, health and social care, mental health and the behavioural sciences were included. A summary of the contents of each database can be found in Table 2. Searches were conducted on the following dates: 10/08/16;01/08/17; $02 / 07 / 18 ; 23 / 07 / 19$. The review was conducted as part of a doctoral thesis which warranted multiple search dates to ensure that the results were up to date prior to submission of the thesis in October 2019. Additionally, supplementary searching was performed on Google Scholar throughout the duration of this review. PROSPERO, the International Prospective Register for Systematic Reviews and the Cochrane Library were searched to ascertain if there were any similar literature or systematic reviews that were ongoing or completed. In this case, there were not.

\section{Selecting the studies}

A total of 438 articles were initially retrieved across the six primary databases (Academic Search Complete, $n=89$; CINAHL, $n=50$; MEDLINE, $n=92$; PsycINFO, $n=40$; Scopus, $n=67$; Web of Science, $n=100$ ) and exported into the reference management software EndNote X8. A further three articles were retrieved from additional sources such as Google Scholar and reference lists from included articles. The duplicate articles $(n=249)$ were removed leaving 192 articles that were first screened against the inclusion/exclusion criteria by title. A total of 59 articles did not meet the inclusion/ exclusion criteria after title screening. Next, the abstracts were read for the remaining 133 articles and they were again screened against the study eligibility criteria. A total of 48 were taken forward for full text screening. Thirty-nine articles were excluded following full-text screening meaning that nine were included in the final review and reported on in the results. The main reason for articles being excluded at full-text screening was due to not reporting any data that directly referred to the role of rural-urban residency on self-management $(n=28)$. Other reasons for exclusion were study participants undergoing active treatment $(n=7)$ or a lack of clarity about whether the participants had completed primary treatment $(n=4)$. Two reviewers (DN and RK) screened by title, abstract and full text and discrepancies around eligibility were reviewed by a third reviewer (IM) until agreement was reached. The search process is reported in Fig. 1.

\section{Charting the data}

The next stage involved charting the data according to an analytical framework that facilitated sorting the material into a data extraction table [38] which can be found in Table 3 . The table was created by the research team in order to meet the study objectives that were posited at the beginning of the review. Data was charted by one researcher (DN) and subsequently checked by another two members of the team (IM and RK). Standard information such as authors, year of publication, study setting, aim, methods, study population, findings in relation to self-management and residency were collected from all included articles.

\section{Collating, summarising and reporting the results}

The final stage was to collate, summarise and report the results of the included studies. This was initially done by one researcher (DN) and then checked for accuracy by two members 
Table 2 Overview of databases searched

\begin{tabular}{|c|c|c|}
\hline Name of database & Contents & Platform/interface \\
\hline Academic Search Complete & Multi-disciplinary journals, reports and proceedings. & EBSCO Host \\
\hline CINAHL & Journals related to nursing and allied health issues. & EBSCO Host \\
\hline MEDLINE & Journals related to life sciences, particularly biomedicine. & Ovid, EBSCO Host \\
\hline PsycINFO & Peer-reviewed journals related to mental health and the behavioural sciences. & EBSCO Host \\
\hline Scopus & $\begin{array}{l}\text { Abstract and citation database of peer-reviewed research literature from scientific, } \\
\text { technical, medical and social science fields and, more recently, also in the arts } \\
\text { and humanities. }\end{array}$ & SciVerse \\
\hline Web of Science & $\begin{array}{l}\text { A multi-disciplinary database containing journals related to medical and social } \\
\text { issues among others. }\end{array}$ & Thomson Reuters \\
\hline PROSPERO & $\begin{array}{l}\text { Protocol details for systematic reviews relevant to health and social care, welfare, } \\
\text { public health, education, crime, justice and international development where } \\
\text { there is a health-related outcome. }\end{array}$ & www.crd.york.ac.uk/prospero/ \\
\hline Cochrane & Database of systematic reviews. & www.cochranelibrary.com/ \\
\hline Google Scholar & Academic literature across a range of publishing formats and disciplines. & scholar.google.com \\
\hline
\end{tabular}

of the team (IM and RK). Scoping reviews aim to provide a descriptive account of the available research and do not normally attempt to appraise the literature utilising a quality assessment tool [38]. Therefore, a quality assessment was not conducted. An overview of the included studies is reported in the results below.

\section{Results}

A total of nine articles were included in the review [39-47]. The studies were published from 2011 to 2018 and conducted in the USA $(n=6)$, Australia $(n=2)$ and Canada $(n=1)$. Out of the nine articles, four used qualitative methods, four used a mixed methods design and one was conducted using solely quantitative methods. Five of the studies were with people affected by breast cancer and the other four included participants who had been affected by a range of cancers.

A qualitative study with African American women from rural Alabama who had been affected by breast cancer $(n=$ 15) [39] highlighted the need for social support from family and friends, as well as healthcare providers. The study highlighted a lack of survivorship education and support in their area. Furthermore, participants identified their needs for information about survivorship self-management, notably around managing treatment-related side effects. Within this context, spirituality and religion were crucial to coping with a cancer diagnosis and the effects of its treatment.

Further qualitative research [40] utilising semi-structured interviews with adults from a rural state in Western America who had completed treatment for cancer $(n=20)$ found four factors (cognitive, affective, interpersonal and symptomatic) that informed self-monitoring which subsequently facilitated a sense of control and self-advocacy. Self-monitoring can be considered a specific self-management strategy that involves patient awareness of thought processes, activities and physical symptoms in addition to the measuring, observing, recording and tracking of signs and symptoms. In terms of cognitive factors, participants collected and critically appraised the information that they were given. Some participants found note taking and recording information helpful to keeping track of and managing their situation. Information came from a range of sources such as health professionals, family, friends, support groups and the internet. Affective factors involved feelings of fear, anxiety, frustration, uncertainty and helplessness. However, these negative emotional responses facilitated a desire to learn about cancer and how best to manage it. Interpersonal relations were vital to learning about cancer, treatment side effects and self-management in general. For some, these were limited to interactions with only health professionals whereas for others, these extended to reliance on friends, family and support groups. Finally, the symptomatic factor refers to adverse treatment side effects, and participants would keep track and document these in the hope of minimising or managing them better in the future. For the most part, these rural participants reported 'active' coping strategies as opposed to 'passive' although there were no comparisons made to those from urban areas.

A recent feasibility study [41] highlighted that it is practical to recruit and retain people affected by breast cancer from rural areas for online focus groups and testing of a webbased education and self-management programme. The study is evidence that rural women are willing to participate in online focus groups and use web-based self-management support. Indeed, this was endorsed as an appropriate selfmanagement tool for managing emotional distress, and [41] the authors maintain that knowing this is important to overcoming negative perceptions about rural internet use and this could be a suitable strategy to improve rural mental health disparities. 


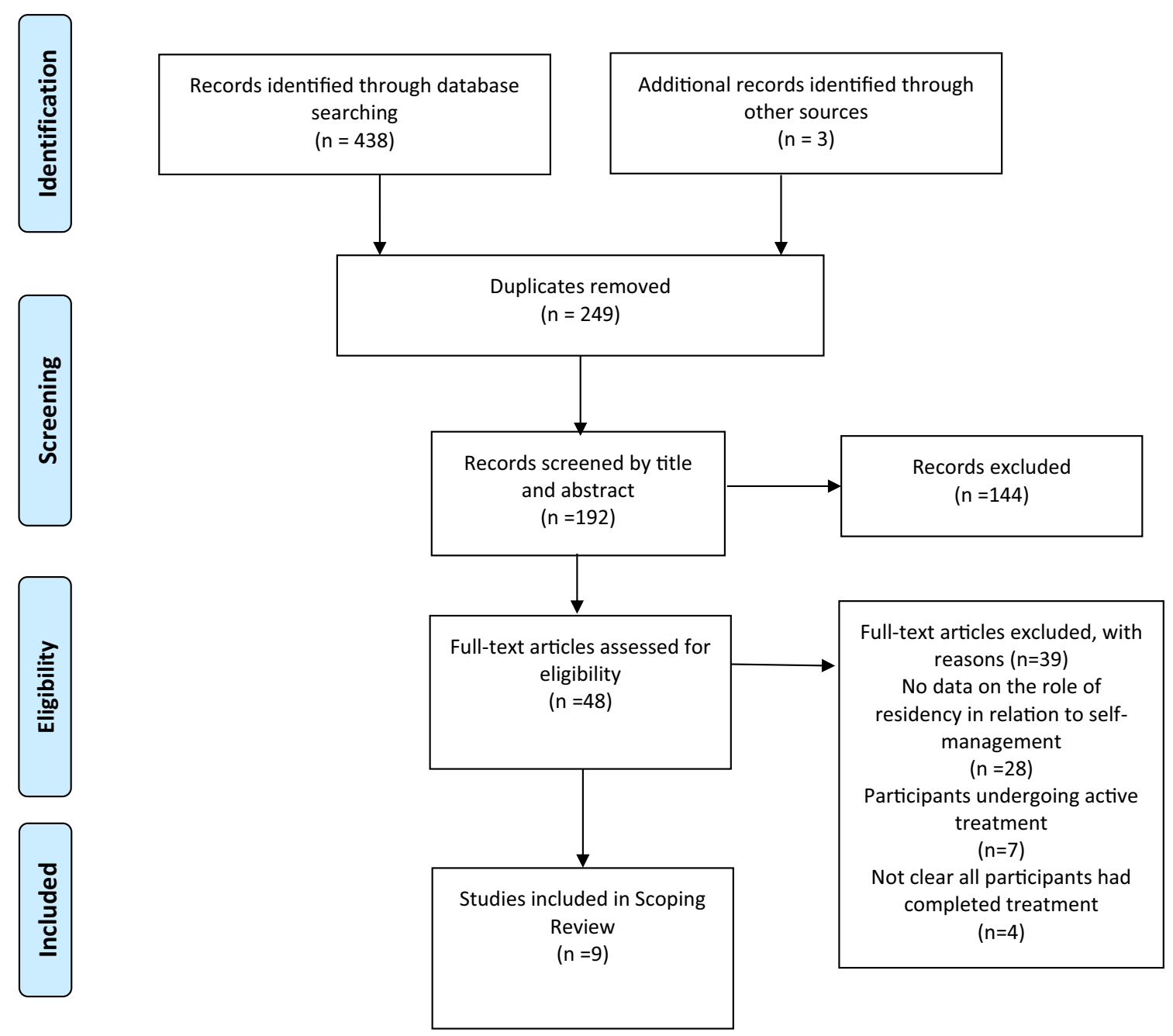

Fig. 1 Flow diagram of scoping review

Further mixed methods research [42] with young women (under 50) who had a diagnosis of breast cancer $(n=105)$ where participants were randomised to two groups (online support group with psycho-education compared with selfhelp psycho-education), indicated that women who were from semi-rural and rural areas benefited from an online support group with psycho-education more so than those from urban areas. Moreover, the online support group that was professionally led supported self-management and facilitated focused and meaningful discussions that reduced illnessrelated stress. Notably, the study was also successful in outreach efforts to rural and semi-rural locations that normally lack psychosocial services and self-management support compared with their urban counterparts.

A qualitative study by [43] examined a yoga intervention as a tool to facilitate self-management with a sample of rural Australian women $(n=15)$ who had experienced lymphoedema as a consequence of treatment for breast cancer. The participants were highly motivated as evidenced by their high level of compliance regardless of having to travel for an hour and a half to attend the yoga sessions. However, the small sample size raises questions as to whether this would be replicable to a larger population. That said, holistic therapies such as yoga offer a range of practices that can be tailored according to the needs of the individual. Participants reported improved well-being and increased awareness of their body, as well as improved physical, mental and social functioning. The intervention also provided a place for them to share experiences with their peers, and the authors argue that yoga has the potential to augment and provide additional benefit to current self-management and treatment practices for women with breast cancer-related lymphedema.

Research into the delivery and development of the Reach Out to Rural Breast Cancer Survivors initiative that was delivered within a rural setting in four rural counties in Northeast Alabama in the USA [44] highlighted four major concerns through content analysis of discussions with sixteen women who were post-treatment. The first major concern was selfmanagement in survivorship. The other three major concerns were fears around being lost in transition, preferences for 
Table 3 Data extraction table

\begin{tabular}{|c|c|c|c|c|c|c|}
\hline Authors & Year & Setting & Aim & Methods & Participants & $\begin{array}{l}\text { Findings in relation to self- } \\
\text { management }\end{array}$ \\
\hline $\begin{array}{l}\text { Adams, N., } \\
\text { Gisiger-Camata, S., } \\
\text { Hardy, C. M., } \\
\text { Thomas, T. F., } \\
\text { Jukkala, A., \& } \\
\text { Meneses, K. }\end{array}$ & 2017 & $\begin{array}{l}\text { Alabama, } \\
\text { USA. }\end{array}$ & $\begin{array}{l}\text { To better understand unique rural } \\
\text { African American breast cancer } \\
\text { survivor survivorship experiences } \\
\text { and needs in the Alabama Black } \\
\text { Belt. }\end{array}$ & $\begin{array}{l}\text { Qualitative (focus } \\
\text { groups/- } \\
\text { interviews) } \\
\text { Survey used } \\
\text { initially for } \\
\text { demographic } \\
\text { and treatment } \\
\text { data. }\end{array}$ & $\begin{array}{l}\text { African } \\
\text { American } \\
\text { breast } \\
\text { cancer } \\
\text { survivors } \\
(n=15)\end{array}$ & $\begin{array}{l}\text { - Importance of social support from } \\
\text { friends/family and healthcare pro- } \\
\text { viders. } \\
\text { - Lack of survivorship education in } \\
\text { the rural setting. } \\
\text { - Participants identified needs for } \\
\text { information about survivorship } \\
\text { self-management, in particular } \\
\text { around managing treatment-related } \\
\text { side effects. } \\
\text { - Spirituality and religion were } \\
\text { prevalent coping strategies. }\end{array}$ \\
\hline $\begin{array}{l}\text { Gisiger-Camata, S., } \\
\text { Adams, N., Nolan, T. } \\
\text { S., \& Meneses, K. }\end{array}$ & 2016 & $\begin{array}{l}\text { Alabma, } \\
\text { USA. }\end{array}$ & $\begin{array}{l}\text { Community-based participatory } \\
\text { research and multi-level assess- } \\
\text { ment were used to (a) engage rural } \\
\text { community leaders, survivors, and } \\
\text { providers; (b) analyse and report } \\
\text { results of discussion groups to } \\
\text { understand survivorship concerns } \\
\text { and preferences; (c) integrate dis- } \\
\text { cussion group findings to develop, } \\
\text { tailor and deliver reach out; and (d) } \\
\text { evaluate reach out with regard to } \\
\text { satisfaction and helpfulness }\end{array}$ & $\begin{array}{l}\text { Mixed methods } \\
16 \text { discussion } \\
\text { groups with } \\
\text { RBCS }\end{array}$ & $\begin{array}{l}\text { Rural breast } \\
\text { cancer } \\
\text { survivors } \\
(n=16)\end{array}$ & $\begin{array}{l}\text { - Self-management concerns: (1) } \\
\text { fatigue, (2) pain, (3) depression, } \\
\text { (4) lymphedema, (5) bone health } \\
\text { osteoporosis, (6) hair loss, (7) sex- } \\
\text { ual function, (8) hot flashes and } \\
\text { menopausal symptoms and (9) co- } \\
\text { morbidities } \\
\text { - Fears around being lost in transition, } \\
\text { preferences around cancer support } \\
\text { and concerns about cancer } \\
\text { surveillance and health. }\end{array}$ \\
\hline $\begin{array}{l}\text { Glasser, M., Nielsen, K., } \\
\text { Smith, S. N., \& Gray, } \\
\text { C. }\end{array}$ & 2013 & $\begin{array}{l}\text { Illinois, } \\
\text { USA. }\end{array}$ & $\begin{array}{l}\text { The purpose of this study was to } \\
\text { collect information to better } \\
\text { understand the psychosocial needs } \\
\text { of rural survivors of cancer and } \\
\text { their significant others. }\end{array}$ & $\begin{array}{l}\text { Quantitative } \\
\text { (survey) }\end{array}$ & $\begin{array}{l}\text { Rural cancer } \\
\text { survivors } \\
(n=29) \\
\text { and } \\
\text { partners } \\
(n=15)\end{array}$ & $\begin{array}{l}\text { - Over half at risk for depression and } \\
34 \% \text { reported some psychosocial } \\
\text { problems - side effects or com- } \\
\text { plications from treatment, emo- } \\
\text { tional support or the impact of } \\
\text { cancer on social relationships. } \\
\text { - Those in rural areas need a team } \\
\text { approach to meeting psychosocial } \\
\text { needs. }\end{array}$ \\
\hline $\begin{array}{l}\text { Lally, R. M., Eisenhauer, } \\
\text { C., Buckland, S., \& } \\
\text { Kupzyk, K. }\end{array}$ & 2018 & $\begin{array}{l}\text { Nebraska, } \\
\text { USA. }\end{array}$ & $\begin{array}{l}\text { To obtain rural breast cancer } \\
\text { survivors' perceptions of the } \\
\text { quality and usability of } \\
\text { CaringGuidance }{ }^{\mathrm{TM}} \text { After Breast } \\
\text { Cancer Diagnosis, a web-based, } \\
\text { psycho-educational, distress } \\
\text { self-management program; and } \\
\text { explore the feasibility of gathering } \\
\text { survivors' perceptions about } \\
\text { CaringGuidance } \\
\text { focus using online } \\
\text { foups. }\end{array}$ & $\begin{array}{l}\text { Primarily } \\
\text { qualitative } \\
\text { (online focus } \\
\text { groups) } \\
\text { Did collect some } \\
\text { demographic } \\
\text { and quant. }\end{array}$ & $\begin{array}{l}\text { Rural breast } \\
\text { cancer } \\
\text { survivors } \\
(n=23)\end{array}$ & $\begin{array}{l}\text { - Practical to recruit and retain rural } \\
\text { people affected by cancer for } \\
\text { research and testing of an } \\
\text { intervention. } \\
\text { - Rural participants willing to } \\
\text { participate with digital } \\
\text { technologies for self-management } \\
\text { (emotional distress) } \\
\text { - Challenges negative findings around } \\
\text { rural internet use. }\end{array}$ \\
\hline $\begin{array}{l}\text { Lawler, S., Spathonis, K., } \\
\text { Masters, J., Adams, J., } \\
\text { \& Eakin, E. }\end{array}$ & 2011 & $\begin{array}{l}\text { Australia } \\
\text { (range of } \\
\text { locations } \\
\text { classed } \\
\text { as } \\
\text { 'rural'). }\end{array}$ & $\begin{array}{l}\text { To explore and examine experiences } \\
\text { and perceptions of follow-up care } \\
\text { (medical and psychosocial) after } \\
\text { active treatment for breast cancer } \\
\text { among women living outside ma- } \\
\text { jor Australian cities. }\end{array}$ & $\begin{array}{l}\text { Qualitative - tele- } \\
\text { phone inter- } \\
\text { views }\end{array}$ & $\begin{array}{l}\text { Rural breast } \\
\quad \text { cancer } \\
\text { survivors } \\
(n=25)\end{array}$ & $\begin{array}{l}\text { - Limited access to medical follow-up } \\
\text { care, psychosocial and lifestyle } \\
\text { support programmes in rural set- } \\
\text { tings. } \\
\text { - Lack of community-based support } \\
\text { programmes was a key concern. } \\
\text { - Some participants given information } \\
\text { about support that was not } \\
\text { available in their area. } \\
\text { - Desire for peer support - proactive } \\
\text { in seeking this using telephone and } \\
\text { the internet. }\end{array}$ \\
\hline $\begin{array}{l}\text { Loudon, A., Barnett, T., } \\
\text { \& Williams, A. }\end{array}$ & 2017 & $\begin{array}{l}\text { Tasmania, } \\
\text { Australi- } \\
\text { a. }\end{array}$ & $\begin{array}{l}\text { To describe the experiences of } \\
\text { women taking part in a yoga } \\
\text { intervention trial for breast } \\
\text { cancer-related lymphoedema. }\end{array}$ & $\begin{array}{l}\text { Qualitative - inter- } \\
\text { views }\end{array}$ & $\begin{array}{l}\text { Rural breast } \\
\quad \text { cancer } \\
\text { survivors } \\
(n=15)\end{array}$ & $\begin{array}{l}\text { - Holistic practices like yoga can be } \\
\text { successful in the rural setting. } \\
\text { - Participants reported improved } \\
\text { well-being, increased awareness of } \\
\text { their body and improved physical, } \\
\text { mental and social functioning. }\end{array}$ \\
\hline
\end{tabular}


Table 3 (continued)

\begin{tabular}{|c|c|c|c|c|c|c|}
\hline Authors & Year & Setting & Aim & Methods & Participants & $\begin{array}{l}\text { Findings in relation to self- } \\
\text { management }\end{array}$ \\
\hline & & & & & & $\begin{array}{l}\text { - Intervention also provided an } \\
\text { opportunity to share experiences } \\
\text { and for peer support. }\end{array}$ \\
\hline $\begin{array}{l}\text { McNulty, J. A., \& Nail, } \\
\text { L. }\end{array}$ & 2015 & $\begin{array}{l}\text { Pacific } \\
\text { Northw- } \\
\text { est, USA }\end{array}$ & $\begin{array}{l}\text { To compare the impact of cancer in } \\
\text { rural- and urban-dwelling adult } \\
\text { cancer survivors living in } 2 \text { regions } \\
\text { of the Pacific Northwest. }\end{array}$ & Mixed methods & $\begin{array}{l}\text { Cancer } \\
\quad \text { survivors } \\
\text { Quantitative } \\
\quad(n=132) \\
\text { Qualitative } \\
\quad(n=19)\end{array}$ & $\begin{array}{l}\text { - Significant differences between } \\
\text { rural and urban respondents } \\
\text { detected. } \\
\text { - The interview highlighted further } \\
\text { differences in relation to accessing } \\
\text { healthcare, care co-ordination, } \\
\text { connecting/community, thinking } \\
\text { about death and dying, } \\
\text { public/private journey and advo- } \\
\text { cacy. } \\
\text { - Rural participants tended to } \\
\text { advocate for themselves, their } \\
\text { diagnosis, survivorship and for } \\
\text { improved healthcare in their } \\
\text { communities. }\end{array}$ \\
\hline $\begin{array}{l}\text { Purtzer, M. A., \& } \\
\text { Hermansen-Kobulnic- } \\
\text { ky, C. J. }\end{array}$ & 2013 & $\begin{array}{l}\text { Wyoming, } \\
\text { USA. }\end{array}$ & $\begin{array}{l}\text { The study objective was to examine } \\
\text { the meaning of self-monitoring } \\
\text { practices within the context of rural } \\
\text { patients' responses to internal and } \\
\text { external information. }\end{array}$ & $\begin{array}{l}\text { Qualitative - } \\
\text { semi-structured } \\
\text { interviews }\end{array}$ & $\begin{array}{l}\text { Cancer } \\
\quad \text { survivors } \\
(n=20)\end{array}$ & $\begin{array}{l}\text { - Cognitive, affective, interpersonal, } \\
\text { and symptomatic factors that } \\
\text { informed self-monitoring which } \\
\text { subsequently facilitated a sense of } \\
\text { control and self-advocacy. } \\
\text { - Cognitive - collected and critically } \\
\text { appraised info they were given, } \\
\text { note taking and recording infor- } \\
\text { mation they were given were } \\
\text { helpful. } \\
\text { - Affective - fear anxiety and frustra- } \\
\text { tion but these negative feelings fa- } \\
\text { cilitated a desire to learn about } \\
\text { cancer and manage it. } \\
\text { - Interpersonal factors (informal and } \\
\text { health professionals) vital to } \\
\text { learning about cancer, treatment } \\
\text { side effects and self-management } \\
\text { in general. } \\
\text { - Symptomatic - adverse treatment } \\
\text { side effects. } \\
\text { - Rural respondents reported 'active' } \\
\text { rather than 'passive' coping } \\
\text { strategies. }\end{array}$ \\
\hline $\begin{array}{l}\text { Stephen, J., Rojubally, } \\
\text { A., Linden, W., } \\
\text { Zhong, L., Mackenzie, } \\
\text { G., Mahmoud, S., \& } \\
\text { Giese-Davis, J. }\end{array}$ & 2017 & $\begin{array}{l}\text { British } \\
\text { Columb- } \\
\text { ia and } \\
\text { Yukon, } \\
\text { Canada. }\end{array}$ & $\begin{array}{l}\text { The study aims were to examine } \\
\text { proof of concept - feasibility, } \\
\text { acceptability and usefulness - and } \\
\text { to hone methods for a formal RCT. }\end{array}$ & $\begin{array}{l}\text { Mixed methods } \\
\text { Feasibility study } \\
\text { with qual } \\
\text { component }\end{array}$ & $\begin{array}{l}\text { Breast } \\
\text { cancer } \\
\text { survivors } \\
(\mathrm{n}=105)\end{array}$ & $\begin{array}{l}\text { - Rural women benefited from online } \\
\text { support group with } \\
\text { psycho-education more so than } \\
\text { those in urban areas. } \\
\text { - The group supported } \\
\text { self-management and facilitated } \\
\text { focused and meaningful discus- } \\
\text { sions that reduced illness-related } \\
\text { stress. }\end{array}$ \\
\hline
\end{tabular}

support and concerns about cancer surveillance and health. The authors then identify a further nine themes from the data that they suggest related to self-management concerns: (1) fatigue, (2) pain, (3) depression, (4) lymphedema, (5) bone health osteoporosis, (6) hair loss, (7) sexual function, (8) hot flashes and menopausal symptoms and (9) comorbidities. These themes were then used to inform the content of the
Reach Out intervention. For example, practical selfmanagement tips on how to locate local resources were integrated into the programme, as well as specific tips to address sexuality and intimacy issues.

A pre-tested survey to ascertain general and mental health, quality of life and demographics with rural people who were personally diagnosed with cancer and was not undergoing any 
active treatment $(n=29)$, and their partners $(n=15)$ [45] showed that over half of those with a personal history of cancer were at risk for depression and 34\% reported some type of psychosocial problem that required assistance, such as management of treatment-related side effects or complications of treatment, emotional support or the impact of cancer on social relationships. Although these findings should be interpreted with caution given the small sample size, the authors suggest that those in rural areas are likely to require a team approach to meeting psychosocial needs.

A qualitative study $(n=25)$ on experiences of follow-up care (medical and psychosocial) following breast cancer treatment for women living outside major Australian cities [46] highlighted that there was limited access to medical followup care, as well as psychosocial and lifestyle support programmes in rural settings. Interestingly, lack of community-based support programmes was a key concern, and some participants were given information about support that was not available in their areas. Several participants wanted peer support with other women affected by cancer; some were proactive in sourcing this in the local area, using the telephone and internet to access this. Furthermore, there should be greater co-ordination of care between health professionals to improve communication and reduce the burden on both, the patient and the medical system.

Finally, a mixed methods study compared the impact of cancer in rural and urban-dwelling adults in two regions of the Pacific Northwest [47] using a questionnaire $(n=$ $132)$, and in-depth interviews ( $n=19)$ showed statistically significant differences between rural and urban when it comes to differences in body concerns, worry, negative impact and employment concerns. The interview data indicated further differences in relation to accessing healthcare, care co-ordination, community, thinking about death and dying, public/private journey and advocacy. Rural participants tended to advocate for themselves, their diagnosis, survivorship and for improved healthcare in their communities. The advocacy emerged as seeking a second opinion, accessing support resources, asking questions and seeking answers and fighting for their financial and employment rights. The rural participants in particular engaged with community advocacy by fundraising, volunteering with survivorship organisations and speaking publicly about survivorship issues.

\section{Discussion}

Firstly, none of the studies that met the eligibility criteria offered direct insight into self-managing cancer within a ruralurban context in the UK. Similar to much of the broader literature on survivorship and geography [30, 35, 48-50], the included studies were conducted in the USA, Canada and
Australia. Whilst the studies that were included in this review shed light on some of the self-management experiences within a rural-urban setting, they are from countries with different healthcare systems and services in comparison with the UK, thus warranting further investigation in a UK setting. Despite the increasing body of work that explicitly focuses on selfmanagement and cancer within a UK context $[13,17,18$, 51-54], there are no studies that have reported data on ruralurban residency in relation to this. Equally, research comparing outcomes between rural and urban people affected by cancer has tended to focus on the post-diagnosis stages, as well as survival rates, and has yet to examine the influence of residency on longer-term survivorship outcomes, such as self-management post-treatment.

Interestingly, eight of the nine articles used some form of qualitative methods, either in isolation or in combination with quantitative methods as a mixed methods design. Qualitative methods seem an appropriate choice to shed light on and explore the in-depth experiences of people affected by cancer; however, there is a considerable need for larger studies with increased sample sizes that utilise quantitative and mixed methods designs. Particularly, where geography is concerned, there is a need for research with a range of cancer types over several different regions so the results can be generalisable to wider rural and urban populations. Much of the research that was included focused on one specific location, with relatively small sample sizes, and in some cases with the same cancer type such as breast $(n=5)$ which limits the extent to which the findings can be inferred to other settings and population groups.

Only two of the included studies collected data from participants in urban areas, as well as rural [42, 47]. Whilst these two studies identified some of the similarities and differences with rural and urban populations in relation to 'self-management', they do not explicitly focus on 'self-management' as one of the primary variables under investigation. Indeed, self-management studies that compare between rural and urban with people affected by cancer are non-existent within the UK and international literature. With that in mind, researchers in psychosocial oncology should be encouraged to collect both quantitative and qualitative data on rural-urban residency to enhance their analyses. Whilst the studies in this review focus directly on rurality signpost to the perceived differences with rural and urban living when presenting their background and context, they do not collect and analyse data from urban populations in their own study which limits the extent to which we can consider these findings unique to the rural setting without a comparator group. Some of the existing American cancer research that has compared between the two on mental health [55], health status and health behaviours $[35,50]$ have used official statistics to categorise and define rural-urban residence, 
and other researchers, where appropriate, should be supported to do the same. In fact, utilising the same methods for defining and measuring rural-urban status would support comparison between researchers, at the very least, on a national and regional level and promote wider collaboration in the field. Furthermore, interventions need to account for geography and the specific traits of rural and urban populations; therefore, cancer survivorship scholars should be encouraged to take note of this when designing and implementing interventions.

With regard to the findings from the studies themselves, they identified the salient needs of those from rural areas and that emotional management seems to be a significant concern [45]. This is not surprising given that geographic and emotional isolation is often associated with rural living as seen in some of the wider literature [56,57]. However, in contrast, it is argued that survivorship experiences are similar regardless of rural-urban residence with the exception of access to specialised survivorship services and resources being the primary difference, as well as a considerable challenge for those in remote locations [44]. A potential solution could be the use of IT and as digital technologies and e-health applications have the potential to support and address needs with rural populations who have been affected by cancer [46]. That said, for this to work, it would be dependent on internet access which can still be limited (or even non-existent) in very rural and remote locations. Indeed, recent work in the UK [58] with people affected by breast cancer suggests that an e-health app could be successful in facilitating peer support and coping strategies. At the same time, it has been shown that social networking does not always provide added benefit, and consideration needs to be given to what stage of the cancer journey this is delivered to the individual [4]. With that in mind, if future time and financial resources are to be invested in the design and utilisation of digital technologies to support health behaviours and self-management, academics and health professionals have a duty to ensure that these are designed and tailored to the needs of both rural and urban populations. Whilst this review was conducted prior to the global pandemic, COVID-19, some people affected by cancer might now feel particularly vulnerable, especially when confined to their homes as a consequence of cancer or other comorbid conditions. It is therefore likely that demand for digital support will increase regardless of geography, where people can learn from professionals and peers without the need for face-to-face contact.

In one study exploring the differences and similarities between rural and urban living [47], the findings challenge the widespread assumption about the perceived negative impact of rural living on health outcomes. Notably, some of the wider literature reinforces a range of characteristics belonging to rural communities that have the potential to benefit people affected by cancer $[22,23]$. Perhaps, not surprisingly, a common theme in the literature is 'community' and research shows that access to healthcare might not be the most salient concern when it comes to the survivorship experience. Social and community support has specifically been accounted for in a framework for recovery of health and well-being in cancer survivorship [15], and it has been posited that community support can differ depending on where an individual lives [22]. This study sheds light on the role of empowerment in rural communities and future researchers in the field should take note. However, the majority of their sample were female and had been affected by a breast cancer diagnosis where there might be more resources available to support recovery and self-management. Additionally, females tend to be more socially active and to seek other forms of social and emotional support compared with males. Nonetheless, the findings highlight some interesting traits of rural communities in relation to cancer survivorship that warrants further data collection with more diverse samples.

\section{Limitations}

Whilst the methods and results from the scoping review identified a gap in the extant literature, notably, that no studies offered direct insight into self-managing cancer within a rural-urban context in the UK, the databases chosen ensured that a wide range of literature in relation to nursing, health and social care, mental health and the behavioural sciences was searched. However, the review was not without its limitations and the search strategy could have been extended to include additional databases such as the Rural and Remote Health Database via Informit Online, although the host institution did not have access at the time of the research. The grey literature was not searched as one of the primary objectives was to map the peer-reviewed academic research in this area. Although to gain a deeper understanding of the field, future reviews should consider exploring the subjectspecific grey literature. Given that this was not a full systematic review, the review protocol was not registered; however, this could have allowed for initial peer review of proposed methods and increased transparency and awareness of the research. Finally, the search terms could have been extended to include related terms such as 'self care', 'self help', 'self education' and 'patient education', thus ensuring a more comprehensive and thorough search of the academic literature.

\section{Conclusion}

Given that a scoping review is not meant to be exhaustive but serves to offer the reader with a good sense of the literature, it 
is possible that some relevant publications were not included. Regardless, the number of included articles $(n=9)$ serves to illustrate that this is an under-researched area, particularly with UK populations, who have completed primary cancer treatment. To date, there is no existing research that examines and compares self-management with people affected by cancer who have completed treatment in rural and urban parts of the UK.

If rural and non-rural populations define their health in different ways as some of the literature suggests, then efforts to support self-management in both populations will need to be better informed by robust evidence given the increasing focus on patient-centred care [59]. It is therefore important to consider if residency can be a predictor of self-management, as well as what acts as a barrier and/or facilitator to self-management; the findings can then be used to inform support that is delivered to people affected by cancer and ensure that it is tailored to population needs in line with geography. Future studies with people affected by cancer should consider collecting data on rural-urban residence where appropriate. This can then be utilised to inform interventions and support based on the needs of both rural and urban populations.

Funding information This work was partially funded my Macmillan Cancer Support.

\section{Compliance with ethical standards}

Conflict of interest The authors declare that they have no conflict of interest.

Open Access This article is licensed under a Creative Commons Attribution 4.0 International License, which permits use, sharing, adaptation, distribution and reproduction in any medium or format, as long as you give appropriate credit to the original author(s) and the source, provide a link to the Creative Commons licence, and indicate if changes were made. The images or other third party material in this article are included in the article's Creative Commons licence, unless indicated otherwise in a credit line to the material. If material is not included in the article's Creative Commons licence and your intended use is not permitted by statutory regulation or exceeds the permitted use, you will need to obtain permission directly from the copyright holder. To view a copy of this licence, visit http://creativecommons.org/licenses/by/4.0/.

\section{References}

1. Maddams J, Utley M, Møller H (2012) Projections of cancer prevalence in the United Kingdom, 2010-2040. Br J Cancer 107(7): 1195-1202. https://doi.org/10.1038/bjc.2012.366

2. Schulman-Green D, Bradley EH, Knobf MT, Prigerson H, Digiovanna MP, Mccorkle R (2011) Self-management and transitions in women with advanced breast cancer. J Pain Symptom Manag 42(4):517-525. https://doi.org/10.1016/j.jpainsymman. 2010.12.007
3. Schulman-Green D, Jaser S, Martin F, Alonzo A, Grey M, Mccorkle R, Whittemore R (2012) Processes of self-management in chronic illness. J Nurs Scholarsh 44(2):136-144. https://doi.org/ 10.1111/j.1547-5069.2012.01444.x

4. Corbett T, Cheetham T, Müller AM, Slodkowska-Barabasz J, Wilde L, Krusche A, Bradbury K (2018) Exploring cancer survivors views of health behaviour change: "where do you start, where do you stop with everything?". Psycho-Oncology 27(7):18161824. https://doi.org/10.1002/pon.4732

5. McCorkle R, Ercolano E, Lazenby M, Schulman-Green D, Schilling LS, Lorig K, Wagner EH (2011) Self-management: enabling and empowering patients living with cancer as a chronic illness. CA Cancer J Clin 61(1):50-62. https://doi.org/10.3322/ caac. 20093

6. Foster C, Calman L, Richardson A, Pimperton H, Nash R (2018) Improving the lives of people living with and beyond cancer: generating the evidence needed to inform policy and practice. J Cancer Policy 15:92-95. https://doi.org/10.1016/j.jcpo.2018.02.004

7. Barlow J, Wright C, Sheasby J, Turner A, Hainsworth J (2002) Self-management approaches for people with chronic conditions: a review. Patient Educ Couns 48(2):177-187. https://doi.org/10. 1016/s0738-3991(02)00032-0

8. Foster C, Brown J, Killen M, Brearley S (2007) The NCRI cancer experiences collaborative: defining self-management. Eur J Oncol Nurs 11(4):295-297. https://doi.org/10.1016/j.ejon.2007.08.002

9. Department of Health, Macmillan Cancer Support \& NHS Improvement (2010) National Cancer Survivorship Initiative Vision. Department of Health, London Available from https:// webarchive.nationalarchives.gov.uk/20100809113601/http:/www. improvement.nhs.uk/cancer/LinkClick.aspx?fileticket= 4apVUSvGcow\%3D\&tabid=214

10. Boland L, Bennett K, Connolly D (2018) Self-management interventions for cancer survivors: a systematic review. Support Care Cancer. https://doi.org/10.1007/s00520-017-3999-7

11. Cimprich B, Janz NK, Northouse L, Wren PA, Given B, Given CW (2005) Taking CHARGE: a self-management program for women following breast cancer treatment. Psycho-Oncology 14(9):704717. https://doi.org/10.1002/pon.891

12. Coffey L, Mooney O, Dunne S, Sharp L, Timmons A, Desmond D, Gallagher P (2016) Cancer survivors' perspectives on adjustmentfocused self-management interventions: a qualitative meta-synthesis. J Cancer Surviv 10(6):1012-1034. https://doi.org/10.1007/ s11764-016-0546-3

13. Davies NJ, Batehup L (2010) Self-management support for cancer survivors: guidance for developing interventions: an update of the evidence. Macmillan Cancer Support, London

14. Dunne S, Coffey L, Sharp L, Timmons A, Desmond D, Gooberman-Hill R, Gallagher P (2018) Barriers to active selfmanagement following treatment for head and neck cancer: survivors perspectives. Psycho-Oncology 27(10):2382-2388. https:// doi.org/10.1002/pon.4835

15. Foster C, Fenlon D (2011) Recovery and self-management support following primary cancer treatment. Br J Cancer 105(Suppl 1):S21S28. https://doi.org/10.1038/bjc.2011.419

16. Foster C, Breckons M, Hankins M, Fenlon D, Cotterell P (2013) Developing a scale to measure self-efficacy to self-manage problems following cancer treatment. Psycho-Oncology 22(S1):16

17. Foster C, Breckons M, Cotterell P, Barbosa D, Calman L, Corner J, Smith PW (2015) Cancer survivors' self-efficacy to self-manage in the year following primary treatment. J Cancer Surviv 9(1):11-19. https://doi.org/10.1007/s1 1764-014-0384-0

18. Foster C, Grimmett C, May CM, Ewings S, Myall M, Hulme C, Richardson A (2015) A web-based intervention (RESTORE) to support self-management of cancer-related fatigue following primary cancer treatment: a multi-centre proof of concept randomised 
controlled trial. Support Care Cancer 24(6):2445-2453. https://doi. org/10.1007/s00520-015-3044-7

19. Gao W, Yuan C (2011) Self-management programme for cancer patients: a literature review. Int Nurs Rev 58(3):288-295. https:// doi.org/10.1111/j.1466-7657.2011.00907.x

20. Howell D, Harth T, Brown J, Bennett C, Boyko S (2017) Selfmanagement education interventions for patients with cancer: a systematic review. Support Care Cancer 25(4):1323-1355. https:// doi.org/10.1007/s00520-016-3500-Z

21. Kim S, Kim K, Mayer D (2017) Self-management intervention for adult cancer survivors after treatment: a systematic review and meta-analysis. Oncol Nurs Forum 44(6):719-728. https://doi.org/10. 1188/17.onf.719-728

22. Reid-Arndt SA, Cox CR (2010) Does rurality affect quality of life following treatment for breast cancer? J Rural Health 26(4):402405. https://doi.org/10.1111/j.1748-0361.2010.00295.x

23. Rogers-Clark C (2002) Living with breast cancer: the influence of rurality on women's suffering and resilience, a postmodern feminist inquiry. Aust J Adv Nurs 20(2):34-39

24. Lankila T, Näyhä S, Rautio A, Koiranen M, Rusanen J, Taanila A (2013) Health and well-being of movers in rural and urban areas - a grid-based analysis of northern Finland birth cohort 1966. Soc Sci Med 76:169-178. https://doi.org/10.1016/j.socscimed.2012.10.021

25. Berg AEVD, Maas J, Verheij RA, Groenewegen PP (2010) Green space as a buffer between stressful life events and health. Soc Sci Med 70(8):1203-1210. https://doi.org/10.1016/j.socscimed.2010. 01.002

26. Bjorklund RW, Pippart JL (1999) The mental health consumer movement: implications for rural practice. Community Ment Health J 35(4):347-359. https://doi.org/10.1023/a:1018714024063

27. Gunn KM, Berry NM, Meng X, Wilson CJ, Dollman J, Woodman RJ, Koczwara B (2019) Differences in the health, mental health and health-promoting behaviours of rural versus urban cancer survivors in Australia. Support Care Cancer 28:633-643. https://doi.org/10. 1007/s00520-019-04822-0

28. Carriere R, Adam R, Fielding S, Barlas R, Ong Y, Murchie P (2018) Rural dwellers are less likely to survive cancer - an international review and meta-analysis. Health Place 53:219-227. https:// doi.org/10.1016/j.healthplace.2018.08.010

29. Singh GK, Williams SD, Siahpush M, Mulhollen A (2011) Socioeconomic, rural-urban, and racial inequalities in US cancer mortality: part I-all cancers and lung cancer and part II — colorectal, prostate, breast, and cervical cancers. J Cancer Epidemiol 2011: 1-27. https://doi.org/10.1155/2011/107497

30. Butow PN, Phillips F, Schweder J, White K, Underhill C, Goldstein D (2012) Psychosocial well-being and supportive care needs of cancer patients living in urban and rural/regional areas: a systematic review. Support Care Cancer 20(1):1-22. https://doi.org/10.1007/ s00520-011-1270-1

31. Arcury TA, Preisser JS, Gesler WM, Powers JM (2005) Access to transportation and health care utilization in a rural region. J Rural Health 21(1):31-38. https://doi.org/10.1111/j.1748-0361.2005. tb00059.x

32. Beck SL, Towsley GL, Caserta MS, Lindau K, Dudley WN (2009) Symptom experiences and quality of life of rural and urban older adult cancer survivors. Cancer Nurs 32(5):359-369. https://doi.org/ 10.1097/ncc.0b013e3181a52533

33. Noyes K, Holub D, Rizvi I, Swanger A, Reisdorf C, Tomaszewski $\mathrm{K}$, Constine LS (2017) Cancer survivorship care in rural community: patient perspective. J Clin Oncol 35(5_suppl):25. https://doi. org/10.1200/jco.2017.35.5_suppl.25

34. Harrison JD, Young JM, Price MA, Butow PN, Solomon MJ (2009) What are the unmet supportive care needs of people with cancer? A systematic review. Support Care Cancer 17(8):11171128. https://doi.org/10.1007/s00520-009-0615-5
35. Weaver KE, Palmer N, Lu L, Case LD, Geiger AM (2013) Ruralurban differences in health behaviors and implications for health status among US cancer survivors. Cancer Causes Control 24(8): 1481-1490. https://doi.org/10.1007/s10552-013-0225-x

36. Jong KE, Smith DP, Yu XQ, Oconnell DL, Goldstein D, Armstrong BK (2004) Remoteness of residence and survival from cancer in New South Wales. Med J Aust 180(12):618-622. https:// doi.org/10.5694/j.1326-5377.2004.tb06123.x

37. Arksey H, O’Malley L (2005) Scoping studies: towards a methodological framework. Int J Soc Res Methodol 8(1):19-32. https://doi. org/10.1080/1364557032000119616

38. Coughlan M, Cronin P (2017) Doing a literature review in nursing, health and social care, 2nd edn. SAGE, London

39. Adams N, Gisiger-Camata S, Hardy CM, Thomas TF, Jukkala A, Meneses K (2017) Evaluating survivorship experiences and needs among rural African American breast cancer survivors. J Cancer Educ 32(2):264-271. https://doi.org/10.1007/s13187-015-0937-6

40. Purtzer MA, Hermansen-Kobulnicky CJ (2013) Being a part of treatment. Cancer Nurs 36(2):93-103. https://doi.org/10.1097/ncc. 0b013e318263f385

41. Lally RM, Eisenhauer C, Buckland S, Kupzyk K (2018) Feasibility of synchronous online focus groups of rural breast cancer survivors on web-based distress self-management. Oncol Nurs Forum 45(6): E111-E124. https://doi.org/10.1188/18.ONF.E111-E124

42. Stephen J, Rojubally A, Linden W, Zhong L, Mackenzie G, Mahmoud S, Giese-Davis J (2017) Online support groups for young women with breast cancer: a proof-of-concept study. Support Care Cancer 25(7):2285-2296. https://doi.org/10.1007/ s00520-017-3639-2

43. Loudon A, Barnett T, Williams A (2017) Yoga, breast cancerrelated lymphoedema and well-being: a descriptive report of women's participation in a clinical trial. J Clin Nurs 26(23-24): 4685-4695. https://doi.org/10.1111/jocn.13819

44. Gisiger-Camata S, Adams N, Nolan TS, Meneses K (2016) Multilevel assessment to reach out to rural breast cancer survivors. Womens Health 12(6):513-522. https://doi.org/10.1177/ 1745505716678232

45. Glasser M, Nielsen K, Smith SN, Gray C (2013) Psychosocial needs of rural survivors of cancer and their partners. J Psychosoc Oncol 31(3):319-333. https://doi.org/10.1080/07347332.2013. 778935

46. Lawler S, Spathonis K, Masters J, Adams J, Eakin E (2010) Followup care after breast cancer treatment: experiences and perceptions of service provision and provider interactions in rural Australian women. Support Care Cancer 19(12):1975-1982. https://doi.org/10. 1007/s00520-010-1041-4

47. McNulty JA, Nail L (2015) Cancer survivorship in rural and urban adults: a descriptive and mixed methods study. J Rural Health 31(3):282-291. https://doi.org/10.1111/jrh.12106

48. Bettencourt BA, Schlegel RJ, Talley AE, Molix LA (2007) The breast cancer experience of rural women: a literature review. Psycho-Oncology 16(10):875-887. https://doi.org/10.1002/pon. 1235

49. Pascal J, Johnson N, Dickson-Swift V, Kenny A (2015) Returning home: psychosocial care during the re-entry phase of cancer survivorship in rural Australia. Eur J Cancer Care 24(1):39-49. https:// doi.org/10.1111/ecc.12232

50. Weaver KE, Geiger AM, Lu L, Case LD (2012) Rural-urban disparities in health status among US cancer survivors. Cancer 119(5): 1050-1057. https://doi.org/10.1002/cncr.27840

51. Henshall C, Greenfield S, Gale N (2017) The role of selfmanagement practices as mechanisms for re-establishing normality in cancer survivors. Qual Health Res 27(4):520-533. https://doi. org/10.1177/1049732316651252

52. Henshall C, Greenfield S, Gale N (2018) Typologies for restructuring relationships in cancer survivorship: temporal 
changes in social support and engagement with self-management practices. Cancer Nurs 41(6):E32-E40. https://doi.org/10.1097/ NCC. 0000000000000538

53. Shneerson CL, Gale NK (2015) Using mixed methods to identify and answer clinically relevant research questions. Qual Health Res 25(6):845-856. https://doi.org/10.1177/1049732315580107

54. Shneerson C, Taskila T, Holder R, Greenfield S, Tolosa I, Damery S, Gale N (2015) Patterns of self-management practices undertaken by cancer survivors: variations in demographic factors. Eur J Cancer Care 24(5):683-694. https://doi.org/10.1111/ecc.12252

55. Burris JL, Andrykowski M (2009) Disparities in mental health between rural and non-rural cancer survivors: a preliminary study. Psycho-Oncology 19(6):637-645. https://doi.org/10.1002/pon. 1600

56. Goins RT, Williams KA, Carter MW, Spencer SM, Solovieva T (2005) Perceived barriers to health care access among rural older adults: a qualitative study. J Rural Health 21(3):206-213. https:// doi.org/10.1111/j.1748-0361.2005.tb00084.x

57. Hewitt M, Greenfield S, Stovall E (eds) (2006) From cancer patient to cancer survivor: lost in transition. The National Academies Press, Washington

58. Brett J, Boulton M, Watson E (2018) Development of an e-health app to support women prescribed adjuvant endocrine therapy after treatment for breast cancer. Patient Prefer Adherence 12:2639 2647. https://doi.org/10.2147/PPA.S187692

59. Gessert C, Waring S, Bailey-Davis L, Conway P, Roberts M, Vanwormer J (2015) Rural definition of health: a systematic literature review. BMC Public Health 15(1):378. https://doi.org/10. 1186/s12889-015-1658-9

Publisher's note Springer Nature remains neutral with regard to jurisdictional claims in published maps and institutional affiliations. 